\title{
A Survey of Internal Governance in Family Business
}

\author{
Qi Lin \\ School of Management, Jinan University, Guangzhou, China \\ Email: ziyegeige@163.com
}

How to cite this paper: Lin, Q. (2018) A Survey of Internal Governance in Family Business. American Journal of Industrial and Business Management, 8, 1093-1100. https://doi.org/10.4236/ajibm.2018.84075

Received: April 4, 2018

Accepted: April 27, 2018

Published: April 30, 2018

Copyright $\odot 2018$ by author and Scientific Research Publishing Inc. This work is licensed under the Creative Commons Attribution International License (CC BY 4.0).

http://creativecommons.org/licenses/by/4.0/

\begin{abstract}
Family businesses play an important role in the global economic environment. In China, more than $90 \%$ of them use family management or family organization. This shows that family-owned companies are playing a decisive role in China's economy. However, with regard to the current development situation, the development status of family-owned enterprises is not optimistic, and the average life expectancy is only 5 years. Facts have proved that internal governance is the key point for the steady development of family-owned enterprises. Internal governance supervision, as an important component of the five elements of internal control, is related to whether the internal management of a family-owned company can be implemented steadily and effectively. Therefore, a sound internal governance supervision system is the key point for whether the family business can survive in the modern economic competitive environment. This review points out the disadvantages of the family business and points out the new direction for the follow-up family business research that applies to the internal governance supervision model of the family business.
\end{abstract}

\section{Keywords}

Family Business, Internal Control Supervision

\section{Introduction}

So far, family businesses have played an indispensable role in companies around the world. The sheer number of companies has forced many people to focus on family businesses. According to conservative estimates by economists, family companies account for $60 \%-80 \%$ of all companies in the world. For Chinese companies, more than $90 \%$ use family management or family organization. With the further development of the market-oriented economy, large and medium-sized family businesses have flourished. According to a statistical data of 
listed companies, as of July 2013, 49.7\% of China's private enterprises are family companies, and family businesses have a large impact on the Chinese economy. Also in all countries of the world, family businesses also occupy an important position. In Europe and the United States, more than half of the companies are family-owned companies, and many companies with great reputation in the industry, such as Disney, Johnson \& Johnson, Wal-Mart and Ford, are among the best in the family business. While creating so many jobs, family businesses also face some restrictions. The life cycle of family enterprises in the Chinese context is relatively short, and there is an old saying that the son inherited his father's business can't pass three generations. Although they are exaggerated, they also reflect the fact that family businesses in the Chinese context are difficult to break through restrictions in family governance. There is a gap between family businesses and modern enterprises. Many family entrepreneurs adopt paternalistic governance. They directly issue first-line instructions to grass-roots employees. This kind of thinking will certainly increase the efficiency of enterprises temporarily. However, with the gradual expansion of enterprises, it will result in unclear power within the company and the consequences of arbitrary setting by various functional departments. Most family-owned enterprises like this one need to find out their defects in structural governance and management systems, and further improvement is the way to win for family business.

As for how to ensure that family businesses can successfully pass on and sustain forever, it is proved that effective internal governance is the key to the steady development of family businesses. Internal control issues have threatened the sustainable development of the company. Based on this scenario, the introduction of the "Basic Norms for Corporate Internal Control" has eased the market demand for internal control norms. On this basis, this paper combined with the characteristics of China's family-owned enterprises, and established a new internal management supervision model applicable to family-owned enterprises. An operative, enforceable, and effective internal control and supervision model ensures the effectiveness of the internal management of the family business, making it more suitable for the current status of the family business in China, and can effectively avoid the failure of the family business caused by the failure of internal control in order to supervise the company and improve its strength. The ability to improve corporate internal control, from the national point of view, is not only conducive to saving government supervision costs, but can further promote taxation. Judging from the family business itself, establishing a sound internal control system can not only avoid many management problems, but also improve business performance and prolong the company's life cycle. Based on the existing model of internal control supervision, combined with the operating characteristics of the family-owned company, this paper establishes a set of internal control supervision models applicable to family-owned companies. This has great theoretical and practical significance for the development of family-owned companies in the future.

This paper studies the current internal management supervision system of 
family enterprises in China and finds out some deficiencies in the internal control of family enterprises in China and proposes further optimization paths. In order to establish a new internal management supervision model suitable for family enterprises, it is more effective to supervise the enterprises and improve the comprehensive strength of the enterprises.

The general structure of this article is as follows:

The first chapter is preface. This article mainly outlines the basis of the topic, research purposes and research value. And on the basis of the present research, this paper provides the innovative analysis, the anticipated difficulties and the solutions.

The second chapter, the topic part, explains the domestic and international research present situation, as well as the internal control supervision related concept and clarifies the relationship between family enterprises and modern enterprises, pointing out the difference between the two.

The third chapter summarizes and forecasts the research of this paper and puts forward the limitation and research contribution.

\section{Feasibility Analysis and Innovation}

1) The Work foundation of this research is more solid

First, this paper is related to the family enterprise internal governance model selection decision, as a management college in reading students, combined with professional theory, can be systematic and professional use of the internal control framework theory for the review and analysis;

Secondly, the institute needs data. There is a professional website and the database resources provided by the school, can effectively use the college research resources for the paper to provide more reliable support;

Finally, the author of this field has a more in-depth understanding, in a serious attitude and efforts can ensure the successful completion of this study.

2) The exploration direction of this research is more practical

This study has a deep analysis on the influence path of different governance modes of family enterprises, which can provide the basis for the decision of the family enterprise to make the choice of internal governance mode. At the same time, after the family enterprises choose relatively more consistent internal governance mode, through adapting to the internal and external environment, the author puts forward some suggestions on the effective inheritance and organization system innovation of the early advantageous resources of family enterprises, which can continuously optimize the internal governance mode selected in different stages and help the family business develop better.

\section{Themes}

\subsection{Research Status at Home and Abroad}

\subsubsection{Foreign Research Status}

When studying the literature related to the internal governance model of foreign family businesses, we can start with the concept of family business and the ele- 
ments of internal control and supervision.

1) Conceptual definition of family business

In the early days, Bames (1976) defined the family business. He pointed out that if the ownership is controlled by the members of the same family, and the family is managed by the members of the same family, it is the family business [1]. Similarly, Handler (1989) has defined the family business earlier [2]. The following factors are the key factors for the family business to distinguish from non-family companies: the proportion of family members in the business, whether ownership and operating rights of the company are controlled by family members. Astrachan and Shanker (2003) defined the family business [3]. An extensive family business was defined as the family controls the development direction of the entire company. The definition of moderation is based on the above definition. It also includes members of the enterprise family who will participate in the daily operations of the company. Relatively narrow family business is not only family control of corporate control but also multi-generational participation in business operations. Danny Miller (2005) believes that family businesses are essentially a diverse set of organizations, however, most are influenced by their social emotional preferences, i.e. the non-economic goals of satisfying family desires, provide work and build reputation for the family [4]. Andres (2011) believes that the family-owned company's management model is the most cost-effective and most efficient one among various forms of business management [5]. This is mainly because family businesses generally do not have only one family member, but instead form a family network with many family members. In this case, the number of external management personnel will be relatively reduced, which will lead to a reduction in external costs; another main factor is to consider the cost of entrusted agency. Although in the family business, some agency-related costs need to be paid in order to coordinate the interests with in the family, this part is far lower than the agency costs in other companies, and companies do not need to pay for the Agency fees to balance ownership and operating rights. The asymmetry of information provided by family businesses to external investors is also lower than other forms of enterprises, which also directly reduces the cost of the company and improves the business performance of the company.

2) About Internal Control Supervision

Xie Zhihua (2009) pointed out that British corporate governance theory developed to its peak in the 1990s [6]. With the prevalence of corporate governance, the company's internal control has gradually received attention. The development of internal control theory has undergone a long process. During this period, internal restraint, internal control system, internal control structure and overall internal control framework have emerged. From 1992 to 1999, the Cadbury report, the Hamper report and the Tesbur report were issued in the United Kingdom. These three reports are the three major milestones in the history of UK corporate governance and internal control research. Chi Guohua (2009) wrote that the Cadbury report believes that effective internal control is an im- 
portant aspect of effective company management and that internal control should be placed under the framework of corporate governance [7]. It also describes the effectiveness of the company's internal control system and stipulates that the audit committee should review the internal control statement issued by the board of directors. Zhangwenfang (2008) considers that internal controls are considered an integral part of effective management in the two major reports immediately followed, the Board is encouraged to strengthen the review of the various aspects of internal control in order to protect the company's assets, strengthen the quality of financial management, assess enterprise risks, comply with laws and regulations, and minimize the risk of fraud [8]. Tian Fei (2013) pointed out that the most influential one is the "Internal Control-Overall Framework" put forward by the COSO Committee in 1994, which clearly pointed out that the control environment is a very important basis for internal control [9].

\subsubsection{Domestic Research Status}

1) Conceptual definition of family business

For the definition of the concept of family business, domestic scholars such as Yin Xiangyan (2009) believe that the following three conditions can be considered as a family business [10]. The family's shareholding ratio is greater than the critical shareholding ratio. Families or relatives within a second-degree relative are members of the board of directors or family of general managers or relatives within the third-degree relatives hold more than half of the board seats of the company. This definition is more precise, and the family business is seen as a continuous distribution from the perspective of equity and business control. From family ownership to critical control, is all family business. Once the critical control is broken, the family business is transformed into a public company. Zhang Xiaomei (2010) pointed out in the "Review of Family Business Governance Research" that family business governance is a formal or non-formal institutional arrangement that regulates and deals with the relationships between family owners, outside owners, family managers, professional managers, and other stakeholders [11]. It adjusted with the development of family business and the change of ownership distribution.

2) About Internal Control Supervision

In the middle and late 1980s, China's internal governance research has only just begun, and research focuses mainly on the concept of internal governance. Li Fengming, Yang Jiwan, and Lou Erxing are experts who began to take the lead in studying internal governance. Yang Jiwanl (1984) proposed to divide internal governance into "management control and accounting control" in "Several Issues Concerning Auditing Theory" [12]. In the 1990s, China's internal governance research mainly proceeded from two aspects. First, from the perspective of auditing, the main representative achievements included: Sun Guangyuan and Qu Shengmin (1992) "Evaluate the role of internal governance system in internal audit” [13], Zhang Jieming (1994) “Modern Auditing and Internal Governance 
[14]" and Liu Liyun's "audit risk and internal governance two aspects of auditing method development". The second is from the aspect of accounting information systems, such as "Introduction to the Internal Management of Accounting Computerized Systems" by Hu Yiming and Chen Jianshen (1996) [15] "Research on the Internal Management of Computer Accounting Systems" published by Huang Zhengrui (1996) [16].

Yu Erli (2003) put forward opinions on the problems existing in the family company's internal governance system. She believes that the principal-agent relationship is the basis for the existence of internal governance, especially for family-owned companies [17]. The internal governance of family-owned companies is generally subject to external environment, risk assessment, information exchange, and monitoring mechanisms.

Xin Jinguo, Zheng Mingna (2006), etc. In order to understand the specific situations of internal governance of family businesses, some surveys were carried out on some enterprises in Zhejiang Province through questionnaires [18]. They found that although most family-owned companies have established internal governance systems, they have generally just started. The future development status is not clear. The survey also found that with the development of the enterprise, the internal management of the family-owned enterprise is gradually strengthened. Usually, when the enterprise enters a mature and stable period, the implementation of the internal governance system is effective, which further explains in the beginning of the growth stage, building internal governance in family businesses can achieve better results.

Zhang Bo (2008) pointed out the part that needs attention in the process of building an internal governance system [19]. He believes that internal governance should be a complete system. When building the system framework of internal governance of family enterprises, it is necessary to coordinate the development of the five elements in order to maximize the effect.

Liu Yuanyuan (2009) conducted a study based on the overall internal governance structure of the family business [20]. She believes that in order to make the internal governance system to be effective, it must first address the drawbacks of the internal governance structure of the family business.

\section{Summary}

Seen from the foreign literature, the family business and internal control of the development process have been very early, and have a relevant research foundation. From the domestic literature, we can see that the internal governance of China's family-owned companies has the following problems: lack of understanding of internal governance, lack of deterrence of position setup; lack of internal constraints family-owned enterprise management; lack of effectiveness of accounting information, assets, and business activity control. China's research on the internal governance of family businesses started late. Although some research results have been obtained, overall, the research is not systematic, com- 
prehensive, and in-depth, and it cannot meet the needs of a flourishing family business. Future research should focus on the establishment of a new internal management supervision model applicable to family businesses, an internal control and supervision model that is operational, implementable, and effective, to ensure the effectiveness of internal management of family businesses and make them more effective, make it more suitable for the development status of family enterprises in China, and effectively avoid the phenomena of enterprise closure caused by the effectiveness of family business due to internal control. It can effectively supervise enterprises and improve their overall strength. In a sense, the internal control supervision has become the bottleneck restricting the further development and expansion of enterprises, so perfecting the internal control system is imminent. The limitation of this paper is that the elaboration should be improved, and there is no detailed summary of the specific design and execution level of internal control. The following five aspects should be considered as the basic thinking and countermeasures of perfecting the internal control of the enterprise: optimizing the internal control environment, strengthening the risk assessment and implementation, perfecting the control activity design, improving the organization communication status, speeding up the information system construction and improving the internal supervision ability. In addition, the government and industry associations in promoting the modernization of family enterprises to support the strength of the study are insufficient.

\section{References}

[1] Jensen, M.M.M. (1976) Theory of the Firm: Managerial Behavior, Agency Costs and Ownership Structure. Social Science Electronic Publishing, 3, 305-360.

[2] Handler, W. (1989) Methodological Issues and Considerations in Studying Family Businesses. Family Business Review, 2, 257-276.

[3] Astrachan, J.H. (2003) Family Businesses' Contribution to the U.S. Economy: A Closer Look. Family Business Review, 16, 211-219.

[4] Group, T.R. (2005) Review of the Turnbull Guidance on Internal Control. The Financial Reporting Council.

[5] Andres, C. (2011) Family Ownership, Financing Constraints and Investment Decisions. Social Science Electronic Publishing, 21, 1641-1659.

[6] Xie, Z.H. (2009) Internal Control: Essence and Structure. Accounting Research.

[7] Chi, G.H. (2009) Construction of the Internal Control Standard Implementation Mechanism for Enterprises: Strategic Orientation and System Integration. Accounting Research, No. 9, 66-71.

[8] Xu, Y.W. and Zhang, W.F. (2008) Evolution of Coso Framework and Its Implications for China. Friends of Accounting, No. 17, 103-104.

[9] Tian, F. (2013) Research on the Internal Control of China's Growing SMEs. Doctoral Dissertation, Shanxi University of Finance and Economics, Taiyuan.

[10] Yin, X.Y. (2009) Driver Analysis and Countermeasures for Establishing a Modern Enterprise System in Family Businesses. Doctoral Dissertation, Southwest Jiaotong University, Chengdu.

[11] Zhang, X.M. (2010) Research on Internal Control System in Corporate Governance 
of Family Enterprises. Doctoral dissertation, Tianjin University of Finance and Economics, Tianjin.

[12] Yang, J.W., Lou, E.X. and Ge, J.P. (1998) Principles of Accounting. 4th Edition, Textbooks for Higher Education Institutions, Beijing.

[13] Sun, G.Y. and Qu, S.M. (1992) Evaluation of the Role of Internal Control Systems in Internal Audit. Audit Research, No. 6, 16-21.

[14] Zhang, J.M. (1994) Modern Auditing and Internal Control. Audit Research, No. 3, 21-24.

[15] Chen, J.S. and Hu, Y.M. (1998) Using Financial Futures for Risk Management. Finance and Accounting, No. 7, 37-39.

[16] Huang, Z.R. (1996) Research on Internal Control of Computer Accounting System. Accounting Research, No. 11, 40-42.

[17] Yu and Li. (2003). Analysis and Thinking of Internal Control Issues in Family Enterprises. Zhejiang Social Sciences, No. 6, 177-180.

[18] Xin, J.G. and Zheng, M.N. (2006) An Empirical Survey of Internal Control in Family Enterprises in Zhejiang Province. Audit Research, No. 5, 85-91.

[19] Ma MuYun. (2008). On the Institutional Innovation of Chinese Family-Owned Enterprises. Modernization of the Market, No. 26, 90-91.

[20] Liu, Y.Y. (2009) Analyzing the Internal Control of Family Enterprises from the Perspective of Governance Structure. Chinese Business, No. 4, 152. 